\title{
Karakteristike jakosti kuka, gležnja i trupa kod osoba s patelofemoralnom boli - razlike među spolovima
}

1 Denisa Manojlović

1,2 Nejc Šarabon

1 Univerza na Primorskem, Fakulteta za vede o zdravju, Izola, Slovenija

2 S2P, Znanost v prakso, d. o. o., Ljubljana, Slovenija gledom trenutačno dostupne literature utvrđena je djelomična zastupljenost MVIC-a područja trupa kod osoba s PFB-om. Također, vidljiv je nedostatak znanstvenih istraživanja MVIC-a područja gležnja i stopala kako kod žena tako i kod muškaraca s PFB-om.

\section{Sažetak}

Uvod: Patelofemoralna bol (PFB) jedna je od najučestalijih boli u području koljena. Smanjena jakost okolnih mišićnih skupina može prouzrokovati lokalne biomehaničke promjene, koje posljedično pridonose razvoju PFB-a. Cilj je našeg rada identificirati, usporediti i procijeniti značajke maksimalne izometričke kontrakcije (MVIC) mišića kuka, trupa i gležnja kod žena i muškaraca s PFB-om. Metode: Izveden je sustavni pregled literature te je za daljnju analizu izabrano devet istraživanja koja su odgovarala unaprijed postavljenim kriterijima. Rezultati: Znatno veći broj istraživanja proučava MVIC mišića kuka u žena s PFB-om nego u muškaraca s istom patologijom. Kod žena su istraživanja složna te izvještavaju o smanjenoj jakosti abduktora, aduktora i ekstenzora kuka, dok su u slučaju dvaju istraživanja koja su proučavala MVIC laterofleksora trupa rezultati oprečni. Našim pretraživanjem nisu nađena istraživanja koje proučavaju utjecaj MVIC-a gležnja kod PFB-a. Zaključak: $U$ oba se spola područje kuka pokazalo potkrijepljeno znanstvenim istraživanjima te su rezultati MVIC-a kod PFB-a na tom području homogeni. Sustavnim pre-

Ključne riječi: patelofemoralna bol, jakost, maksimalna izometrička kontrakcija, kuk, gležanj, trup

Datum primitka: 09.04.2020.

Datum prihvaćanja: 01.07.2020.

https://doi.org/10.24141/1/6/2/9

Adresa za dopisivanje:

Denisa Manojlović

A: Fakulteta za vede o zdravju, Univerza na Primorskem

Polje 42, 6310 Izola, Slovenija

E-pošta: denisa.manojlovic@fvz.upr.si

$\mathrm{T}:+385989394672$ 


\section{Uvod}

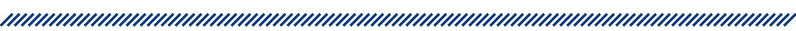

Patelofemoralna bol (PFB) ili prednja bol u koljenu kronično je stanje koje uzrokuje dugoročne subjektivne $\mathrm{i}$ objektivne poteškoće te je jedna od najučestalijih boli u području koljena. ${ }^{1,2}$ Predominantna značajka PFB-a jest difuzna peripatelarna ili retropatelarna bol koja se javlja tijekom izvođenja opterećujućih aktivnosti za koljenski zglob (npr. čučnjevi, skokovi, produženo sjedenje i trčanje). ${ }^{3,4}$ lako se pokazalo da PFB osjeti između $3 \%$ i $15 \%$ fizički aktivne populacije, ${ }^{5}$ incidencija je najviša u adolescenciji. ${ }^{6,7}$ Dokazano je da je približno svaki četrnaesti adolescent osjetio PFB barem jednom tijekom godine koja je prethodila ispitivanju. ${ }^{4}$ Kada govorimo o razlikama između žena i muškaraca, pokazalo se da je učestalost PFB-a veća u žena. Dokazano je kako postoji dvostruko veća vjerojatnost da će se PFB pojaviti u osobe ženskog spola nego u osobe muškog spola., ${ }^{4,8}$

Bez obzira na veliko zanimanje koje PFB izaziva svojom prevalencijom u općoj populaciji, etiologija nastanka ovoga stanja još nije u potpunosti razumljiva. Mehanizmi nastanka PFB-a složeni su i ovise o nekoliko čimbenika, ${ }^{3,9,10}$ pri čemu se vjeruje da biomehanički i strukturni čimbenici imaju najveći utjecaj na povećanje opterećenja patelofemoralnoga zgloba. ${ }^{11,12}$ Utjecaj trupa, zdjelice i kukova nazivamo proksimalnim čimbenicima za razvoj PFB-a, dok je lokalno u središtu zanimanja kontaktna površina između interkondilarne fose femura i patele. Kod distalnih čimbenika rizika naglasak je poglavito na stopalima i gležnjevima. ${ }^{13,14}$ Svi ovi čimbenici samostalno ili u međusobnoj interakciji pridonose razvoju sila opterećenja na patelofemoralni zglob i posljedično na pojavu PFB-a.

lako je zajednički utjecaj segmenata trupa i donjih ekstremiteta važan za razumijevanje etiologije nastanka PFB-a, novija istraživanja stavljaju primarni fokus na utjecaj proksimalnih čimbenika. Jakost mišića uključenih u razvoj PFB-a važan je dio sagledavanja cjelokupne slike stanja pojedinca. Upravo je iz toga razloga potrebno utvrditi temeljne deficite i razlike jakosti mišića između spolova. Testiranje maksimalne voljne izometričke kontrakcije (engl. maximal voluntary isometric contraction; MVIC) standardizirana je metoda ocjene mišićne jakosti kako kod zdravih osoba tako i pri raznim mišićno-koštanim i neuromuskularnim stanjima. ${ }^{15}$ Smanjena jakost mišića trupa i kuka može uzrokovati lokalne biomehaničke promjene koje u konačnici pridonose razvoju
PFB-a. Za cjelovitu sliku jakosti mišića trupa i donjih ekstremiteta potrebno je razmotriti i proučiti mišićne skupine koje svojim kontrakcijama proizvode silu u sve tri ravnine. $U$ čeonoj je ravnini kod žena s PFB-om vidljivo smanjenje MVIC-a abduktora kuka. ${ }^{1,16,17}$ S obzirom na razlike među spolovima po pregledu literature pokazala se potreba za dodatnim istraživanjima koja bi proučavale MVIC na muškom uzorku s PFB-om te usporedila dobivene rezultate sa ženskim uzorkom iste problematike. Stoga je za zaokruživanje slike jakosti mišića u čeonoj ravnini potrebno identificirati potencijalne deficite jakosti pri muškom spolu.

Kada govorimo o deficitima pri PFB-u prisutnima u središnjoj ravnini, najizraženija je smanjena jakost ekstenzora kuka., ${ }^{716} \mathrm{U}$ žena s PFB-a utvrđeno je da je manjak jakosti MVIC-a ekstenzora kuka prisutan samo uz istodobnu fleksiju koljena. S obzirom na to da se s promjenom kuta u koljenu promijeni i uloga mišića stražnje lože, taj deficit nestane pri ispruženom položaju koljena. Dva su potencijalna razloga za to: slabost dvozglobnih mišića pri istodobnoj fleksiji koljena ili povećana jakost dvozglobnih mišića pri ekstenziji koljena, što je posljedično znak slabosti jednozglobnih ekstenzora kuka. ${ }^{16,18}$ Uočen je nedostatak kvalitetnih istraživanja kojima su različiti oblici kontrakcije i zglobnih kutova u središtu interesa, jer da bi dobivene informacije pomogle u razvoju preventivnih mjera ili primjerenih rehabilitacijskih programa za osobe s PFB-om. Također, važno je napomenuti da su žene s PFB-om pokazale statistički značajno smanjenje MVIC-a ekstenzije koljena. ${ }^{17}$ Kod muškaraca postoji nedostatak istraživanja koja bi sa sigurnošću potvrdila ili opovrgnula takve tvrdnje.

Također, pretpostavlja se da su i promjene jakosti unutarnje te vanjske rotacije kuka izražene u osoba s PFB-om. Kod muškaraca je ustanovljena povećana jakost vanjskih rotatora kuka, dokje kod žena upravo suprotno, povećana jakost unutarnjih rotatora kuka u usporedbi sa zdravom populacijom. Posljedično se kod žena pokazalo smanjenje jakosti vanjskih rotatora kuka, ${ }^{8,16}$ premda malobrojna istraživanja nisu pokazala promjene jakosti unutarnjih rotatora kuka u usporedbi sa zdravim pojedincima.

Cilj je ovog rada usporedba i procjena MVIC-a mišića kuka i lateralnih fleksora trupa kod muškaraca s PFB-om i bez PFB-a. Nadalje je cilj rada proučavanje i utvrđivanje značajki i razlika MVIC-a mišića trupa i kuka između žena i muškaraca s PFB-om. Prepoznavanje ključnih razlika koje prevladavaju u žena i muškaraca s PFB-om pridonijet će cjelovitoj slici etiologije nastanka PFB-a, što je od iznimne važnosti pri oblikovanju optimalnog preventivnog $i$ rehabilitacijskog programa za osobe s PFB-om. 


\section{Metode}

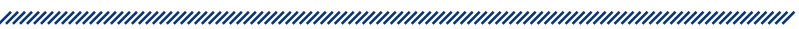

Izveden je sustavni pregled literature te je pretraživanje relevantnih članaka provedeno tijekom listopada 2019. Pregledana je zbirka podataka PubMed s pomoću sljedeće kombinacije pojmova, koja je rezultirala sa 107 rezultata: ( ${ }^{*}$ patell ${ }^{*}$ OR anterior knee) AND (pain OR syndrome) AND ((hip OR proximal joint*) OR (torso OR back) OR (ankle OR foot)) AND (characteristic* OR predictive OR factor ${ }^{\star}$ OR aspect ${ }^{\star}$ ) AND (weeks OR months).

Nakon prvotnog pregleda, utvrdila se relevantnost pojedinih članaka u pogledu odabrane teme te je u pregled uključeno 35 članaka, od kojih su 32 dobivena u punom tekstu. Po detaljnom pregledu iz daljnje je analize isključeno 23 članka iz razloga neprimjerene metodologije ili proučavane populacije. Konačno je u priloženi sustavni pregled literature uključeno devet članaka. Svih devet članaka bilo je usredotočeno na proučavanje MVIC-a mišića kuka pri PFB-u. Dva od njih dodatno su proučavala i MVIC mišića trupa, dok s nave- denom kombinacijom pojmova nije nađen nijedan članak koji bi se usredotočio na poveznicu između MVIC-a mišića gležnja i PFB-a.

Tijek pretraživanja prikazan je na slici 1.

\section{Rezultati}

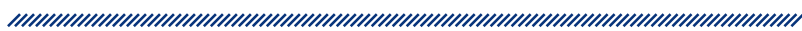

Deficiti MVIC-a mišića kuka, trupa i gležnja mogu prouzročiti biomehaničke promjene, koje posljedično znatno pridonose razvoju PFB-a. Uzimajući u obzir morfološke i biomehaničke razlike među spolovima, razumno je daljnje proučavanje utjecaja MVIC-a na učestalost i rizik nastanka PFB-a pri oba spola. U nastavku su opisane studije koje su se usredotočile na proučavanje MVIC-a mišića kuka i trupa pri PFB-u te je važno istaknuti da s navedenom kombinacijom pojmova nije nađena nijedna studija koja istražuje MVIC mišića gležnja pri PFB-u.

\begin{tabular}{|c|c|c|c|c|}
\hline Autor i godina & Uzorak (n) & Spol & Mišićna skupina & Rezultati \\
\hline $\begin{array}{l}\text { Megalhaes i sur. } \\
\qquad(2010)\end{array}$ & $n=100(P F B=50, K G=50)$ & Ž & $\begin{array}{l}\text { ABD, ADD, ER, IR, FLEX, } \\
\text { EXT kuka }\end{array}$ & $\begin{array}{c}\text { Smanjenje MVIC-a mišića kuka ( } 12 \%-36 \%) \\
\text { za sve mišićne skupine. }\end{array}$ \\
\hline $\begin{array}{l}\text { Almeida i sur. } \\
\qquad(2016)\end{array}$ & $n=43(P F B=22, K G=21)$ & Ž & $\begin{array}{l}\text { ABD, EXT, ER kuka i } \\
\text { LFlex trupa }\end{array}$ & $\begin{array}{c}\text { Smanjenje MVIC-a pri PFB-u ( } 15,6 \%-27,9 \%) \\
\text { za sve mišićne skupine osim LFlex. }\end{array}$ \\
\hline $\begin{array}{l}\text { Ferreira i sur. } \\
\qquad(2019 a)\end{array}$ & $n=76(P F B=38, K G=38)$ & Ž & ABD kuka & $\begin{array}{l}\text { Smanjenje MVIC-a ABD kuka pri PFB-u } \\
\qquad(28,3 \%) .\end{array}$ \\
\hline $\begin{array}{l}\text { Ferreira i sur. } \\
\qquad(2019 b)\end{array}$ & $n=60(P F B=30, K G=30)$ & Ž & ABD kuka & Smanjenje MVIC-a ABD kuka pri PFB-u (33 \%). \\
\hline $\begin{array}{l}\text { Bolgla i sur. } \\
\qquad(2015)\end{array}$ & $\mathrm{n}=102(\mathrm{PFB}=66, \mathrm{KG}=36)$ & M & ABD, ER, IR, EXT kuka & $\begin{array}{l}\text { Nije utvrđena statistički značajna razlika } \\
\text { između PFB-a i KG-a. }\end{array}$ \\
\hline $\begin{array}{l}\text { Hoglund i sur. } \\
\qquad(2018)\end{array}$ & $n=72(P F B=36, K G=36)$ & M & ABD, ER, EXT kuka & $\begin{array}{l}\text { Smanjenje MVIC-a EXT kuka PFB u odnosu na } \\
\text { KG. U slučaju ostalih mišićnih skupina nije } \\
\text { utvrđena statistički značajna razlika. }\end{array}$ \\
\hline $\begin{array}{l}\text { Rathleff i sur. } \\
\qquad(2013)\end{array}$ & $n=40(P F B=20, K G=20)$ & $M / Z ̌$ & $\mathrm{ABD}, \mathrm{ADD}, \mathrm{ER}, \mathrm{IR}$ kuka & $\begin{array}{l}\text { Nije utvrđena statistički značajna razlika } \\
\text { između PFB-a i KG-a. }\end{array}$ \\
\hline $\begin{array}{l}\text { Nunes i sur. } \\
\text { (2019) }\end{array}$ & $n=32(P F B=16, K G=16)$ & $M / Z ̌$ & ABD, EXT kuka & $\begin{array}{l}\text { Smanjenje MVIC-a ABD i EXT kuka pri PFB-u } \\
\qquad(21 \% \text { i } 25 \%) .\end{array}$ \\
\hline $\begin{array}{l}\text { Cowan i sur. } \\
\text { (2009) }\end{array}$ & $n=37(P F B=10, K G=27)$ & $M / Z ̌$ & $\begin{array}{l}\text { ABD, ER kuka i LFlex } \\
\text { trupa }\end{array}$ & $\begin{array}{l}\text { Smanjenje MVIC-a LFlex trupa skupine s PFB- } \\
\text { om ( } 29 \%) \text {. Nije utvrđena statistički značajna } \\
\text { razlika u slučaju MVIC-a ABD i ER kuka. }\end{array}$ \\
\hline \multicolumn{5}{|c|}{$\begin{array}{l}\text { Legenda: PFB - patelofemoralna bol; KG - kontrolna grupa; Ž - žene; M - muškarci; MVIC - maksimalna voljna izometrička kontrakcija; } \\
\text { ADD - aduktori; ABD - abduktori; ER - vanjski rotatori kuka; IR - unutarnji rotatori kuka; FLEX - fleksori; EXT - ekstenzori; LFlex - } \\
\text { laterofleksori trupa }\end{array}$} \\
\hline
\end{tabular}




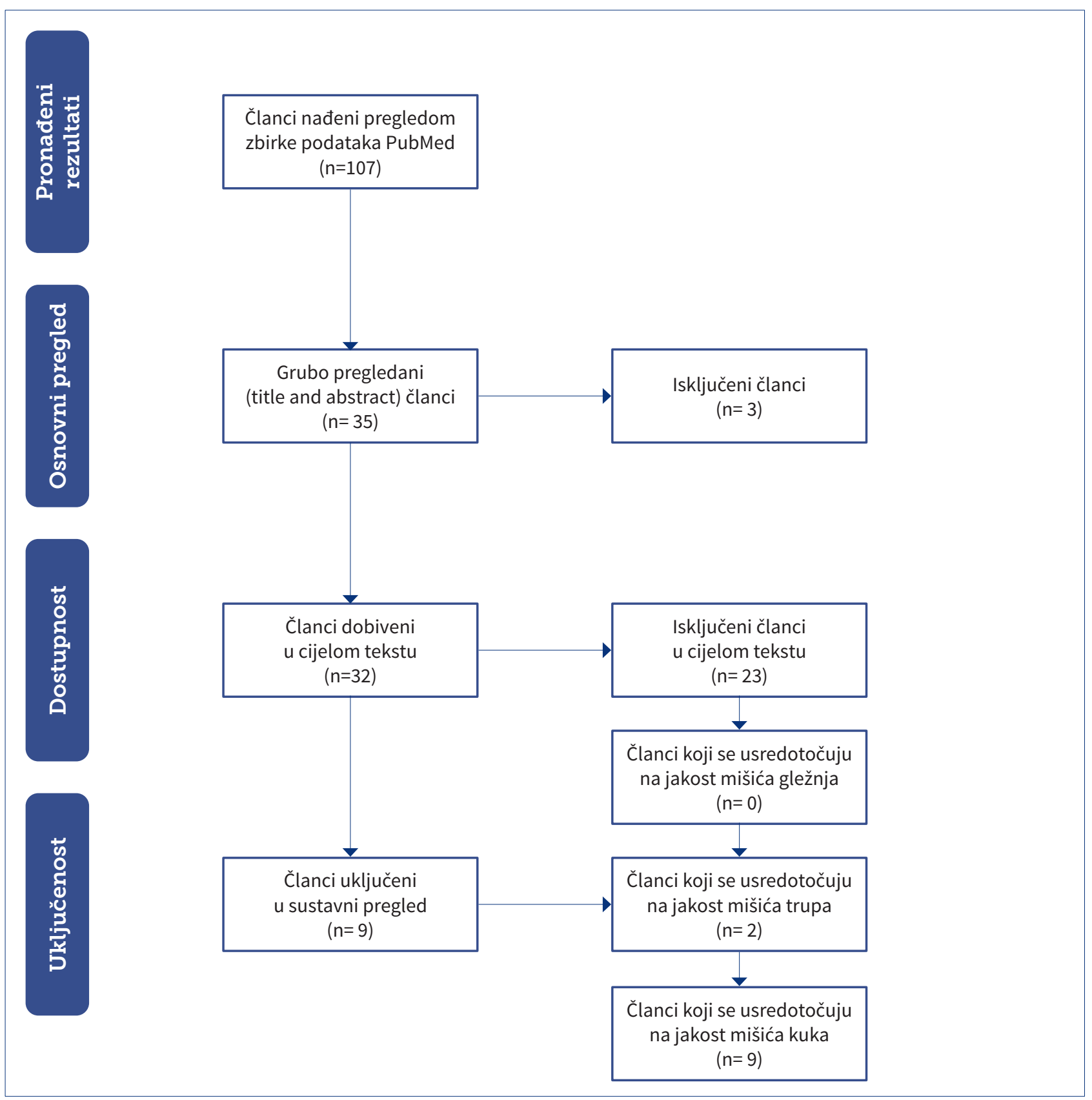

\section{Slika 1. Dijagram tijeka po protokolu PRISMA}

(engl. Preferred Reporting Items for Systematic Reviews and Meta-Analyses)

\section{Jakost mišića kuka}

Uzimajući u obzir dokazano višu incidenciju PFB-a u žena, ne iznenađuje činjenica da različite studije uspoređuju MVIC abduktora kuka u žena s PFB-om i bez PFB$a,{ }^{16,17,19}$ dok je onih koji potonje proučavaju u muškaraca osjetno manje..$^{20,21}$

Rezultati navedenih istraživanja izvještavaju o smanjenoj vrijednosti MVIC-a abduktora kuka u žena s PFB-om u usporedbi s kontrolnom grupom (KG). ${ }^{16,17,19}$ Ustanovljeno je da u žena s PFB-om vidljiv deficit MVIC-a abduktora kuka od $15 \%$ do $20 \%(p<0,002)$ u usporedbi s KGom. ${ }^{19}$ Drugi su autori na uzorku $(n=43)$ žena s PFB-om i bez PFB-a ocjenjivali povezanost dinamičnoga valgusa koljena i MVIC-a mišića kuka. Autori zaključuju da je u žena s PFB-om prisutan veći dinamički valgus koljena i smanjena jakost mišića kuka među kojima i abduktora kuka $(18,2 \%, p=0,017)$ u usporedbi s KG-om bez 
PFB-a. ${ }^{16}$ Konačno, autori koji su se usredotočili na jakost abduktora kuka žena s PFB-om pri izometričkoj, koncentričnoj i ekscentričnoj kontrakciji izvještavaju o smanjenoj jakosti navedene mišićne skupine za proučavane vrste kontrakcije $(28,3 \%, 21,8 \%$ i $17 \%)$ u usporedbi s KG-om. Ustanovljeno je da, iako postoje značajne razlike među skupinama za sve tri vrste mišićne kontrakcije, najizraženije su u slučaju MVIC-a. ${ }^{17}$

Za razliku od žena s PFB-om, muškarci s istim bolnim sindromom nisu pokazali smanjene vrijednosti MVIC-a abduktora kuka. ${ }^{20,21}$ Jedna od proučavanih studija uključila je 102 muškarca s PFB-om i bez PFB-a. Osnovni cilj istraživanja bio je usporediti jakost mišića kuka između spolova. Ustanovljeno je da je, za razliku od žena, razlika između skupina bila 7,5 \% ( $p=0,27)$ u korist KG-a, što nije statistički značajna razlika. ${ }^{21}$ Iste zaključke potvrđuju i autori koji su na uzorku $(n=72)$ muškaraca ustvrdili da u muškaraca s PFB-om nije vidljivo smanjenje MVIC-a abduktora kuka u odnosu na KG $(p=0,14) .{ }^{20}$

U slučaju studija koje su uključivale oba spola možemo zaključiti da su rezultati oprečni. Boling i sur. ${ }^{8}$ te Rathleff i sur. ${ }^{22}$ zaključuju da nisu vidljivi deficiti MVIC-a abduktora kuka skupine pojedinaca s PFB-om u usporedbi s KGom bez PFB-a. U kohortnu studiju čiji je cilj bio utvrditi poveznicu između odabranih biomehanički varijabli i rizika za nastanak PFB-a autori su uključili 4543 zdravih pojedinaca oba spola. Ispitanici su praćeni u razdoblju od četiri godine te je zaključeno da se rizični čimbenici razlikuju između spolova, iako nisu povezani s MVIC-o, kuka. ${ }^{8}$ Rathleff i sur. ${ }^{22}$ usredotočili su se na MVIC donjih ekstremiteta $u$ adolescenata s PFB-om $(n=40)$. Autori ističu da nisu prisutne statistički značajne promjene MVIC-a abduktora kuka adolescenata s PFB-om u odnosu na zdrave adolescente bez PFB-a. U suprotnosti su s navedenim tvrdnjama rezultati studija koje izvješćuju o značajnom smanjenju MVIC-a abduktora kuka kod pojedinaca s PFB-om u usporedbi s KG-om bez PFB-a., ${ }^{1,23}$ Nunes i sur. ${ }^{23}$ na uzorku od 22 pojedinaca s PFB-om i bez PFB-a ustvrdili su statistički značajno smanjenje MVIC-a abduktora kuka skupine s PFB-om. Nakagawa i sur. ${ }^{1}$ potvrđuju rezultate potonje studije i izvješćuju o značajnom smanjenju MVIC-a abduktora kuka u usporedbi s KG-om bez PFB-a $(p<0,001)$ te ističu kako je u žena taj deficit izraženiji $(p<0,001)$.

lako je potrebno uzeti u obzir utjecaj fleksora kuka na razvoj i pogoršanje sindroma PFB-a, zaključujemo kako je smanjenje MVIC-a ekstenzora kuka najizraženiji deficit u središnjoj ravnini u pojedinaca s PFB-om. U žena s PFB-om prisutna je poveznica između dinamičkog valgusa koljena i smanjenja MVIC-a ekstenzora kuka te je taj deficit dosegnuo $27,9 \%(p<0,01)$ u odnosu na KG bez PFB-a. ${ }^{16}$ Rezultate navedene studije potvrđuju i drugi autori, koji izvješćuju o smanjenju MVIC-a ekstenzora kuka skupine s PFB-om od $15 \%$ u odnosu na KG $(p=0,037) .{ }^{19}$ Kada govorimo o MVIC-u ekstenzora kuka kod muškaraca s PFB-om, po sustavnom pregledu literature zaključujemo kako su rezultati uključenih studija oprečni. Bolgla i sur. ${ }^{21}$ nadopunjuju rezultate koji u muškaraca ne ukazuju na statistički značajnu razliku abduktora kuka skupine s PFB-om u odnosu na KG te izvješćuju kako ni u slučaju ekstenzora kuka razlika od 9,8 \% u korist KG-a nije statistički značajna $(p=0,26)$. Oprečne su rezultate dobili Hoglund i sur., ${ }^{20}$ koji ističu kako je u muškaraca vidljiv deficit MVIC-a ekstenzora kuka $(p<0,02)$ s naglaskom na najveći stražnjični mišić (m. gluteus maximus) kao najvažnijim čimbenikom ovoga zaključka.

Kindel i sur. ${ }^{18}$ i Nunes i sur. ${ }^{23}$ izvješćuju o smanjenju MVIC-a ekstenzora kuka na uzorku sastavljenom od oba spola s PFB-om i bez PFB-a. U prvom je slučaju $(n=18)$ MVIC ekstenzora kuka izmjeren u četiri različita položaja kuka i pri dva različita kuta fleksije koljena $\left(0^{\circ}\right.$ i $\left.90^{\circ}\right)$. Autori zaključuju da nije bilo statistički značajne razlike između skupina u slučaju potpune ekstenzije koljena $(p=0,256)$. Pri $90^{\circ}$ fleksije koljena pokazalo se smanjenje MVIC-a $(p=0,029)$ ekstenzora kuka u skupini s PFB-a pri svakom od četiri ispitivana položaja kuka. ${ }^{18}$ Nunes $\mathrm{i}$ sur. ${ }^{23}$ potvrđuju rezultate navedene studije te izvješćuju da su pojedinci s PFB-om pokazali 25-postotno smanjenje MVIC-a te da je posljedična razlika između skupina statistički značajna $(p=0,02)$.

Pretpostavlja se da smanjenje MVIC-a vanjske rotacije kuka ima utjecaj na razvoj PFB-a. Za dublje razumijevanje promjena u poprečnoj ravnini potrebno je uzeti u obzir utjecaj kako vanjskih tako i unutarnjih rotatora te ekstenzora kuka, koji imaju dvojnu funkciju vanjske rotacije i ekstenzije.

Megalhaes i sur. ${ }^{19}$ te Almeida i sur. ${ }^{16}$ izvješćuju o smanjenju MVIC-a vanjskih rotatora kuka u žena s PFB-om u usporedbi s KG-om žena bez PFB-a. Autori navode kako su, uz deficite MVIC-a u čeonoj i središnjoj ravnini, kod žena s PFB-om prisutni i deficiti onih mišića koji poglavito djeluju u poprečnoj ravnini. Skupina žena s PFB-om pokazala je 15,6 \% niži MVIC vanjskih rotatora kuka u usporedbi sa ženama bez PFB-a $(p=0,02)$. Zaključuju da bi poboljšanje MVIC-a vanjskih rotatora moglo znatno pridonijeti sprječavanju prekomjernoga medijalnog pomaka kuka i posljedično pozitivno utjecati na PFB. ${ }^{16}$ Navedeni rezultati u skladu su s daljnjim studijama koje su na uzorku od 100 žena potvrdile statistički značajno smanjenje MVIC-a vanjskih rotatora kuka u žena s PFB-om. ${ }^{19}$ 
U muškaraca s PFB-om studije su složne te izvješćuju da nisu opaženi deficiti MVIC-a vanjskih rotatora skupine $s$ PFB-om u usporedbi s KG-om. ${ }^{20,21}$ Bolgla i sur. ${ }^{21}$ ističu kako se, za razliku od žena, u muškaraca ne pokazuje smanjenje MVIC-a mišića kuka, među kojima i vanjskih rotatora. Pokazala se razlika od $8,3 \%(p=0,21)$ jakosti MVIC-a vanjskih rotatora kuka u korist KG-a te kao takva nije dosegnula statističku značajnost. Unatoč tome, autori upozoravaju da su muškarci s PFB-om pokazali $13,4 \%(p=0,13)$ niži MVIC unutarnje rotacije kuka, iako se ni ta vrijednost nije pokazala statistički značajnom. Zaključke navedene studije potvrđuju i Hoglund i sur., ${ }^{20}$ koji ističu kako među muškarcima s PFB-om nisu vidljivi deficiti MVIC-a vanjskih rotatora kuka $(p>0,017)$.

Slično kao u odraslih, ni u adolescenata se između skupina nije pokazala značajna razlika koda MVIC-a rotatora kuka. ${ }^{22}$ Rezultati navedene studije navode da deficiti vanjskih $(p=0,44)$ ili unutarnjih $(p=0,85)$ rotatora nisu statistički značajni.

\section{Jakost mišića trupa}

Malobrojne studije koje se usredotočuju na MVIC laterofleksora trupa izvješćuju o oprečnim rezultatima. Almeida i sur. ${ }^{16}$ na uzorku $(n=43)$ žena s PFB-om i bez PFB-a zaključili su da ne postoje statistički značajni deficiti laterofleksora trupa skupine s PFB-om u usporedbi s KG-om $(p=0,82)$.

Autori navode da nije ustanovljeno postojanje poveznice između MVIC-a laterofleksora trupa i dinamičnog valgusa koljena kako u skupini s PFB-om tako i u KG-u. Suprotno ovim navodima, Cowan i sur. ${ }^{24}$ izvješćuju da je na uzorku od 37 pojedinaca oba spola vidljivo smanjenje MVIC-a laterofleksora trupa od $29 \%$ skupine s PFBom u usporedbi s KG-om ( $p=0,03$ ).

S obzirom na malobrojne i oprečne podatke o utjecaju MVIC-a laterofleksora trupa na PFB, potrebne su daljnje studije koje bi razjasnile važnost te mišićne skupine u oba spola s PFB-om.

\section{Zaključak}

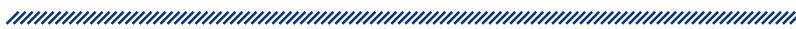

lako se u praksi pokazalo da je izvor promijenjene kinematike gibanja pri PFB-u povećana unutarnja rotacija i adukcija te smanjena ekstenzija kuka, možemo dodatno zaključiti kako je u pozadini prisutan i smanjeni kapacitet mišića gležnja i stopala te kuka i trupa.

$\mathrm{Na}$ temelju sustavnog pregleda trenutačno dostupne literature zaključujemo kako je rezultatima istraživanja samo djelomično obuhvaćeno područje trupa, dok je vidljiva izrazita potreba dodatnih istraživanja u području gležnja i stopala. Područje kuka pokazalo se znanstveno utemeljeno te su rezultati istraživanja o smanjenju MVIC-a mišića kuka donekle homogeni. Važno je istaknuti kako unatoč brojnim istraživanjima na području kuka kod PFB-a još uvijek nije sa sigurnošću ustanovljena uzročno-posljedična veza između pojave PFB-a i smanjenja MVIC-a mišića kuka. Zaključujemo kako je smanjenje MVIC-a mišića kuka potencijalno posljedica otprije prisutnog PFB-a te je samim time mehanizam prilagodbe na bol ili je smanjenje MVIC-a uzrok te je već u izvoru razlog za pojavu PFB-a.

U svrhu objektivne ocjene jakosti susjednih zglobova kod PFB-a potrebna su, kako u slučaju gležnja i stopala tako i u slučaju trupa i kuka, dodatna znanstvena istraživanja. Preporuka je da se buduća istraživanja usredotoče na proučavanje MVIC-a gležnja i stopala kod osoba s PFB-om. Odgovori na otvorena pitanja o jakosti mišića gležnja i stopala pri PFB-u nužni su u svrhu terapeutskoga usmjeravanja primarne i sekundarne preventive. Također, potrebno je omogućiti dublje razumijevanje MVIC-a mišića trupa kod ljudi s PFB-om, s naglaskom na laterofleksore, s obzirom na to da rezultati predstavljenih istraživanja samo djelomično pokrivaju spomenuto područje. Konačno, poželjno je ustanoviti uzročnoposljedičnu vezu između smanjenja MVIC-a mišića kuka i nastanka PFB-a kako bi se primjereno oblikovali i usmjerili preventivni i rehabilitacijski pristupi za osobe s PFB-om. 


\section{Referencije}

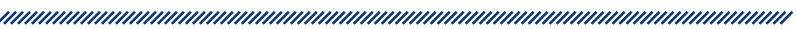

1. Nakagawa TH, Moriya ET, Maciel CD, Serrao FV. Frontal plane biomechanics in males and females with and without patellofemoral pain. Med Sci Sports Exerc.2012; 44(9): 1747-1755.

2. Glaviano NR, Baellow A, Saliba S. Physical activity levels in individuals with and without patellofemoral pain. Phys Ther Sport. 2017; 27: 12-16.

3. Crossley KM, Stefanik JJ, Selfe J, Collins NJ, Davis IS, Powers CM, McConnell J et al. Patellofemoral pain consensus statement from the 4th International Patellofemoral Pain Research Retreat, Manchester. Part 1: Terminology, definitions, clinical examination, natural history, patellofemoral osteoarthritis and patient-reported outcome. Br J Sports Med. 2016; 50: 839-843.

4. Smith BE, Selfe J, Thacker D, Smith BE, Selfe J, Thacker D, Hendrick P, Bateman M, Moffatt F et al. Incidence and prevalence of patellofemoral pain: A systematic review and meta-analysis. PLoS One. 2018; 13(1): e0190892.

5. Neal BS, Barton CJ, Gallie R, OHalloran P, Morrissey D. Runners with patellofemoral pain have altered biomechanics which targeted interventions can modify: a systematic review and meta-analysis. Gait Posture. 2016; 45: 69-82.

6. Molgaard C, Rathleff MS, Simonsen O. Patellofemoral pain syndrome and its association with hip, ankle, and foot function in 16- to 18-year-old high school students: a single-blind case-control study. J Am Podiatr Med Assoc. 2011; 101: 215-222.

7. Galloway RT, Xu Y, Hewett TE, Barber Foss K, Kiefer AW, DiCesare CA. Age-Dependent Patellofemoral Pain: Hip and Knee Risk Landing Profiles in Prepubescent and Postpubescent Female Athletes. Am J Sports Med. 2018; 46(11): 2761-2771.

8. Boling M, Padua D, Marshall S, Guskiewicz K, Pyne S, Beutler A. Gender differences in the incidence and prevalence of patellofemoral pain syndrome. Scand J Med Sci Sports. 2010; 20(5): 725-730.

9. Khayambashi K, Mohammadkhani Z, Ghaznavi K, Lyle MA, Powers CM. The effects of isolated hip abductor and external rotator muscle strengthening on pain, health status, and hip strength in females with patellofemoral pain: a randomized controlled trial. J Orthop Sports Phys Ther. 2012; 42(1): 22-29.

10. Bertelsen ML, Hulme A, Petersen J, Brund RK, Sørensen $H$, Finch CF, Parner ET, Nielsen RO. A framework for the etiology of running-related injuries. Scand J Med Sci Sports. 2017; 27: 1170-1180.

11. Saad MC, Felício LR, de Lourdes Masullo C, Liporaci RF, Bevilaqua-Grossi D. Analysis of the center of pressure displacement, ground reaction force and muscular activity during step exercises. Journal of Electromyography and Kinesiology. 2011; 21(5): 712-718.
12. Fox A, Ferber R, Saunders N, Osis S, Bonacci J. Gait Kinematics in Individuals with Acute and Chronic Patellofemoral Pain. Med Sci Sports Exerc. 2018; 50(3): 502-509.

13. Almonroeder TG, Benson LC. Sex differences in lower extremity kinematics and patellofemoral kinetics during running. J Sports Sci. 2017; 35(16): 1575-1581.

14. Mirzaie GH, Rahimi A, Kajbafvala M, Menshadi FD, Kalantari KK, Saidee A. Electromyograghic activity of the hip and knee muscles during functional tasks in males with and without patellofemoral pain. J Bodyw Mov Ther. 2019; 23(1): 54-58.

15. Meldrum D, Calahane E, Conroy R, Fitzgerald D, Hardiman O. Maximum voluntary isometric contraction: Reference values and clinical application. Amyotroph Lateral Scler. 2007; 8(1): 47-55.

16. Almeida GP, Silva AP, França FJ, Magalhães MO, Burke TN, Marques AP. Relationship between frontal plane projection angle of the knee and hip and trunk strength in women with and without patellofemoral pain. J Back Musculoskelet Rehabil. 2016; 27; 29(2): 259-266.

17. Ferreira AS, de Oliveira Silva D, Barton CJ, Briani RV, Taborda B, Pazzinatto MF, de Azevedo FM. Impaired Isometric, Concentric, and Eccentric Rate of Torque Development at the Hip and Knee in Patellofemoral Pain. J Strength Cond Res. 2019.

18. Kindel C, Challis J. Joint Moment-Angle Properties of the Hip Extensors in Subjects With and Without Patellofemoral Pain. J Appl Biomech. 2018; 34(2): 159-166.

19. Megalhaes E, Fukuda TY, Sacramento SN, Forgas A, Cohen $\mathrm{M}$, Abdalla RJ. A comparison of hip strength between sedentary females with and without patellofemoral pain syndrome. J Orthop Sports Phys Ther. 2010; 40(10): 641-647.

20. Hoglund LT, Burns RO, Stepney AL. Do males with patellofemoral pain have posterolateral hip muscle weakness? Int J Sports Phys Ther. 2018; 13(2): 160-170.

21. Bolgla LA, Earl-Boehm J, Emery C, Hamstra-Wright K, Ferber R. Comparison of Hip and Knee Strength in Males With and Without Patellofemoral Pain. Phys Ther Sport. 2015; 16(3), 215-221.

22. Rathleff CR, Baird WN, Olesen JL, Roos EM, Rasmussen $S$, Rathleff MS. Hip and Knee Strength Is Not Affected in 12-16 Year Old Adolescents with Patellofemoral Pain - A Cross-Sectional Population-Based Study. PLoS One. 2013; 8(11): e7915.

23. Nunes GS, de Oliveira Silva D, Pizzari T, Serrão FV, Crossley KM, Barton CJ. Clinically measured hip muscle capacity deficits in people with patellofemoral pain. Phys Ther Sport. 2019; 35: 69-74.

24. Cowan SM, Crossley KM, Bennell KL. Altered hip and trunk muscle function in individuals with patellofemoral pain. Br J Sports Med. 2009; 43(8): 584-588. 


\section{STRENGTH CHARACTERISTICS OF HIP, ANKLE AND TRUNK MUSCLES IN PERSONS WITH PATELLOFEMORAL PAIN - GENDER DIFFERENCES}

1 Denisa Manojlović

${ }_{1,2}$ Nejc Šarabon

1 University of Primorska, Faculty of Health Sciences, Izola, Slovenia

2 S2P, Science to practice, Ltd., Laboratory for Motor Control and Motor Behavior, Ljubljana, Slovenia

\section{Summary}

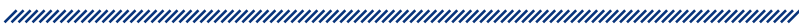

Introduction: Patelofemoral pain (PFP) is one of the most common pain conditions in the knee area. The reduced strength of the surrounding muscle groups can cause local biomechanical changes, which subsequently contribute to the development of PFP. The aim of our review is to compare and evaluate the maximal voluntary isometric contraction (MVIC) of the hip, trunk, and ankle muscles in men and women with PFP. Methods: A systematic review of the literature was performed and 9 studies were selected for further analysis that fit the pre-set criteria. Results: A significantly larger number of studies have studied hip MVIC in women with PFP than in men with the same pathology. Studies in women report reduced abductor, adductor and hip extensor strength, while in the case of two studies that examined lateral flexors of the trunk MVIC, the results were conflicting. Our search did not find any studies that examined the effect of MVIC of ankle or foot muscles on PFP in men or women. Conclusion: Regarding the MVIC in PFP, the hip area has proven to be the most scien- tifically examined in both man and women and the results are homogeneous. This systematic review of the currently available literature has identified the partial representation of the MVIC of the trunk area in individuals with PFP. Also, there is a lack of scientific research regarding the MVIC of the ankle and foot area in both women and men with PFP.

Keywords: patellofemoral pain, strength, maximal voluntary isometric contraciton, hip, ankle, trunk 